\title{
Green Supplier Evaluation and Selection in Apparel Manufacturing Using a Fuzzy Multi-Criteria Decision-Making Approach
}

\author{
Zhaoxia Guo, Haitao Liu, Dongqing Zhang and Jing Yang * \\ Business School, Sichuan University, Chengdu 610065, China; zx.guo@alumni.polyu.edu.hk (Z.G.); \\ haitaoliuch@gmail.com (H.L.); dqzhang1123@gmail.com (D.Z.) \\ * Correspondence: zg2176@gmail.com; Tel.: +86-28-8541-7867; Fax: +86-28-8541-5628 \\ Academic Editor: Bin Shen \\ Received: 27 March 2017; Accepted: 14 April 2017; Published: 20 April 2017
}

\begin{abstract}
With the increasing environmental awareness, apparel manufacturers have begun to consider environmental issues in supplier evaluation and selection. It is crucial to assess suppliers based on their environmental performance along with other criteria for supplier selection. This paper addresses the green supplier evaluation and selection problem in global apparel manufacturing by developing a methodological framework for green supplier evaluation and selection based on the triple bottom line principle and a fuzzy multi-criteria decision-making (MCDM) model. First, a green supplier evaluation criteria hierarchy based on the triple bottom line principle is established based on comprehensive literature review, on-site investigation and policy analysis. Then, a fuzzy MCDM model is presented to evaluate and select the best material supplier. Finally, a sensitivity analysis is conducted to verify the effectiveness of the proposed framework. Results show that the proposed framework can handle green supplier evaluation and selection in apparel manufacturing effectively.
\end{abstract}

Keywords: apparel production; supplier selection; fuzzy axiomatic design; evaluation criteria; triple bottom line

\section{Introduction}

Today's apparel supply chain is characterized by short product life cycles, volatile and unpredictable customer demands, tremendous product varieties, and long supply processes [1]. The global apparel enterprises must keep on looking for ways to improve the operations' performance and the market competitiveness in a sustainable and effective manner.

Supplier evaluation and selection is critical for manufacturing firms since its performance determines the quality of the procurement, and ultimately affect the firm's operations performance and market competitiveness [2]. Supplier selection and management could be used to increase the competitiveness of the entire supply chain [3]. Recently, due to the governmental legislation and an increased awareness of environmental responsibility, global apparel manufacturing firms have begun to consider environmental issues in their supply chain operations $[4,5]$.

Research on green supplier evaluation and selection has attracted more and more attention from academic and industrial sectors [6,7]. Some researchers developed the framework to measure the environmental performance of suppliers [8]. But there is still a lack of a comprehensive methodology with strong practicability to evaluate and select the green supplier. Various techniques are used to evaluate and to select suppliers, such as analytical hierarchy process (AHP), analytic network process (ANP), data envelopment analysis (DEA) and so on. However, these approaches can only get the results, but not analyze the supplier $[9,10]$. Moreover, these approaches are not practical in industrial practice because of their high computational complexity. 
To overcome the limitations of these existing methods, we develop an indicator hierarchy for green supplier evaluation for apparel manufacturing by considering environmental concerns and provide clear definitions of these indicators. A fuzzy axiomatic design (FAD)-based multi-criteria decision-making (MCDM) model is presented to evaluate the supplier performance. The FAD technique was developed by Kulak and Kahraman [11] for decision making problems, which can not only select the best green supplier but also analyze the alternative supplier for the requirement, and it shows great advantages when comparing to the other approaches.

\subsection{Green Supplier Evaluation Criteria}

Supplier evaluation is the first step of selecting appropriate suppliers, which is crucial to the performance of supply chain operations.

Dickson [12] first began to systematically study the supplier selection problem and identified 23 supplier evaluation criteria. Weber et al. [13] reviewed, annotated, and classified 74 related articles which had appeared since 1966 . With global climate change, academicians and purchasing practitioners began to focus on the environmental aspect. Noci [14] developed a conceptual approach to assess a supplier's environmental performance. Lu et al. [15] applied the environmental principles to green supplier selection in electronics industry including materials, energy use, solid residue, liquid residue and end of life. Lee et al. [16] presented a fuzzy extended analytic hierarchy approach for evaluating and selection green suppliers and considered quality, technology capability, total product life cycle cost, green image, pollution control, environment management, green product and green competencies. Grisiet et al. [17] considered both traditional parameters (economic efficiency) and environmental ones when making the green supply chain management and availability of "clean" technologies, ecological materials, environmental policies, environmental planning, ISO14001, green image and current environmental impact were identified as the assessment criteria for green supplier selection. Chen et al. [18] proposed delivery, quality, flexibility, green design, green purchasing, life cycle assessment, ISO 14000 certificates, R\&D green products, cleaner production and environmental management system for green supplier selection. Kuo and Lin [19] used analysis network process (ANP) and data envelopment analysis (DEA) to select green vendors and considered environmental administration system, environmental system, environmental planning and green purchasing. Kannan et al. [20] identified 7 evaluation criteria to evaluate the environmental performance of green supplier, including environment protection, corporate social responsibility, pollution control, green product, green image, green innovation, hazardous substance management.

However, most previous studies have not taken carbon emissions as an environmental impact measure into account [21]. Moreover, the existing green supplier selection framework does not clearly define the selection criteria, which may lead decision makers give the unsuitable assessment to the alternative suppliers [10].

It is well-known that the triple bottom line (TBL) principle, proposed by Elkington [22], can be used to help the industry and the society to achieve the sustainability from economic, social and environmental perspectives. It is usually adopted as the foundation for the performance evaluation in green and low-carbon context. This paper thus aims to propose a TBL-based green supplier evaluation criteria hierarchy for apparel manufacturing and gives a clear definition for each criterion.

\subsection{Triple Bottom Line Principle for Performance Evaluation}

The triple bottom line principle emerged was proposed as a practical tool for performance evaluation of sustainability, and it has been harnessed in many fields [23], such as nonprofits, governments, community and businesses [24,25]. Hubbard [23] proposed a TBL-based, sustainable balanced scorecard conceptual framework for evaluating organizational performance. Some nonprofit organizations have employed the TBL principle to evaluate their sustainable performance, and especially more and more state, regional and local governments pay attention to the TBL framework and have applied it into policy making [25,26]. Rogers and Ryan [27] proposed a sustainable 
community development framework based on the TBL principle for enhancing community wellbeing, facilitating economic vitality and weakening environmental impact. Today's enterprises get to pay close attention to the environmental sustainability due to cap-and-trade regulation [28,29]. Therefore, some performance evaluation frameworks for enterprise based on TBL theory have been proposed. For example, Govindan et al. [2] proposed a fuzzy multi criteria approach according to TBL theory for sustainable supplier selection. Nikolaou et al. [30] proposed a reverse logistics social responsibility evaluation framework based on the TBL approach. Sarkis and Dhavale [31] combined the TBL approach and business operations and proposed a framework for evaluating and selecting sustainable suppliers. However, the adoption of the TBL principle in apparel manufacturing has not been reported so far although the apparel industry has hugely negative influences on global environment [32-34]. Therefore, it is essential for apparel manufacturing to evaluate and select green supplier based on the effective TBL principle.

\subsection{Green Supplier Selection Approaches}

Supplier selection is a complex MCDM problem because there may be conflicts between qualitative and quantitative criteria. Extensive MCDM approaches have been proposed to deal with the supplier selection problem, such as the analytical hierarchy process [14,16], analytic network process [35,36], mathematical programming [37,38], data Envelopment Analysis [39,40], elimination and choice expressing reality (ELECTRE) [41,42], technique for order performance by similarity to ideal solution (TOPSIS) [43,44], fuzzy set theory [45], and their hybrids $[15,16,19,43,46]$ and so on.

Handfield et al. [47] used AHP approach to evaluate the relative importance of various environmental traits and to access the relative performance of several suppliers along these traits. Levary [48] applied the AHP approach to rank foreign suppliers based on supply risks. Amid et al. [49] proposed a weighted max-min model based AHP for green supplier selection. Hsu and $\mathrm{Hu}[50,51]$ used ANP to select green supplier and applied it in hazardous substance management in electronic industry. Wu and Blackhurst [39] used the DEA approach to assess the performance of green supplier. Kumar et al. [52] proposed a comprehensive approach based on DEA with carbon footprint monitoring, so called Green DEA for supplier selection. Ng [37] developed weighted linear programming (LP) model to deal with the green supplier selection problem. Che [53] proposed a genetic algorithm-based (GA) model to solve multi-period supplier selection problem. Chiou et al. [54] used confirmatory factory analysis to measure the influence of greening the suppliers and green innovation on environmental performance. Feyzioglu and Buyukozkan [55] applied choquet integral approach evaluate green suppliers considering decision criteria dependencies. Large and Thomsen [56] used structural equation model to select green supplier mainly considered environmental criteria.

Many researchers combined multiple methods to evaluate green supplier. Wang et al. [57] used AHP and TOPSIS under fuzzy situation for supplier selection. Yan [58] introduced GA combined with current weights obtained by AHP of supplier to dynamically adjust weights. Kuo and Lin [19] proposed a model of DEA and ANP considering the interdependency between criteria to conduct the supplier selection based on environmental criteria. Kannan et al. [59] integrated fuzzy multi attribute utility theory and AHP, TOPSIS and MOLP for ranking green suppliers and then allocating the optimum order quantities among them. Govindan et al. [2] structurally reviewed green supplier selection papers published from 1996 to 2011 and concluded that the most frequently used technique is AHP (27.78\%), followed by ANP (16.6\%), DEA (11.1\%), LP (8.76\%), TOPSIS (5.56\%), and multi-objective optimization $(2.77 \%)$.

However, these widely-used MCDM approaches, described above, focused on the selection of the best supplier but did not analyze the criteria of alternative suppliers or failure causes.

This paper proposed a fuzzy MCDM model, which has the capability of both analyzing the criteria of alternative suppliers or failure causes and selecting the best supplier. However, seldom research has reported the use of FAD for supplier selection. The FAD approach has been applied to handling various decision making problems, such as selection of transportation companies [11], 
ranking of intercity bus passenger seats [60], choice of the most appropriate technology [61], selection the best alternatives among shipyards [62], selection of logistics tool [63], However, there are only a few applications of FAD in supply chain management [64].

This research thus develops a methodological framework for green supplier evaluation and selection based on the triple bottom line principle and a FAD-based fuzzy multi-criteria decision-making (MCDM) model. The main contribution of this paper is to propose a methodological framework for green supplier evaluation and selection, in which a TBL-based green supplier evaluation criteria hierarchy is developed for evaluating green suppliers and a fuzzy MCDM model is presented to select the best green suppliers in global apparel manufacturing.

The rest of the paper is organized as follows. The proposed methodological framework for green supplier evaluation and selection is presented in Section 2. Section 3 gives the evaluation criteria and defines each criterion. Section 4 presents the fuzzy MCDM model. A case study is conducted to evaluate the effectiveness of proposed framework in Section 5. Section 6 gives conclusions and future research directions.

\section{Methodological Framework for Green Supplier Evaluation and Selection}

The proposed framework for green supplier evaluation and selection is illustrated in Figure 1 and it mainly consists of three stages. First, the green supplier selection criteria are identified from the comprehensive literature review, on-site investigation and the policy analysis according to the triple bottom line principle. Various realistic features in supplier selection of global apparel manufacturing are considered. Second, the validity of green supplier selection criteria is assessed by senior purchasing experts with rich industry experience, and then we further modify the green supplier selection criteria until the validity of criteria is satisfactory according to the feedbacks of experts. Then the experts evaluate alternative suppliers through linguistic terms. The best alternative is selected via the fuzzy multi-criteria decision-making model, which is mainly made up of four procedures, including transformation of experts' grading determining functional requirements, calculating information contents and evaluating and selecting the best alternatives. These procedures of the fuzzy multi-criteria decision-making model will be introduced in Section 4 in detail.

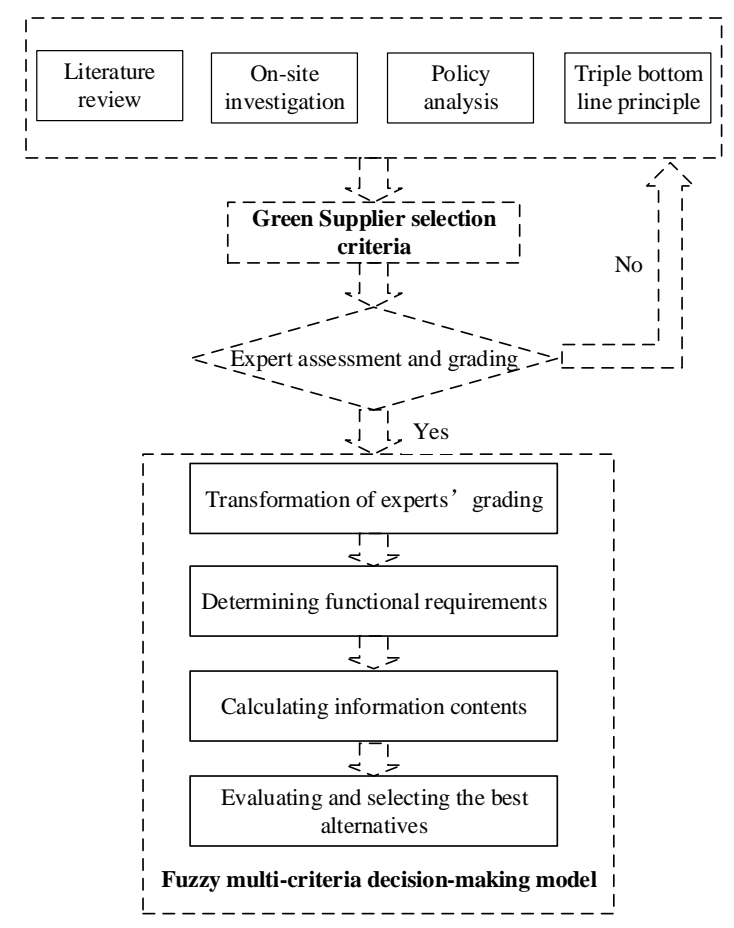

Figure 1. Methodological framework for green supplier evaluation and selection. 


\section{Green Supplier Evaluation Criteria in Apparel Manufacturing}

The traditional evaluation criteria of supplier selection were constructed generally from cost, quality, and service perspectives. In the literature, most criteria have not taken into account some important indicators of supplier evaluation, such as the carbon emissions in production and transportation operations, and transportation costs [7,10,21]. Moreover, these indicators have not been defined clearly in the literature. This section attempts to construct a comprehensive system of green supplier evaluation criteria in global apparel manufacturing with clear definitions. Considering the characteristics of the low carbon economy and the global apparel supply chain, we establish a green supplier evaluation criteria hierarchy with 6 main criteria and 10 sub-criteria based on the TBL principle, which is shown in Table 1 . The six categories criteria include quality $C_{1}, \operatorname{cost} C_{2}$, delivery $C_{3}$, technology $C_{4}$, service $C_{5}$, and environmental competency $C_{6}$, which involves economic, social and environmental perspectives. The economic indicators include quality, cost, delivery, and technology criteria. The service criterion belongs to the social indicator. The environmental competency criteria belong to the environmental indicator.

Table 1. Evaluation criteria of green supplier selection and definitions.

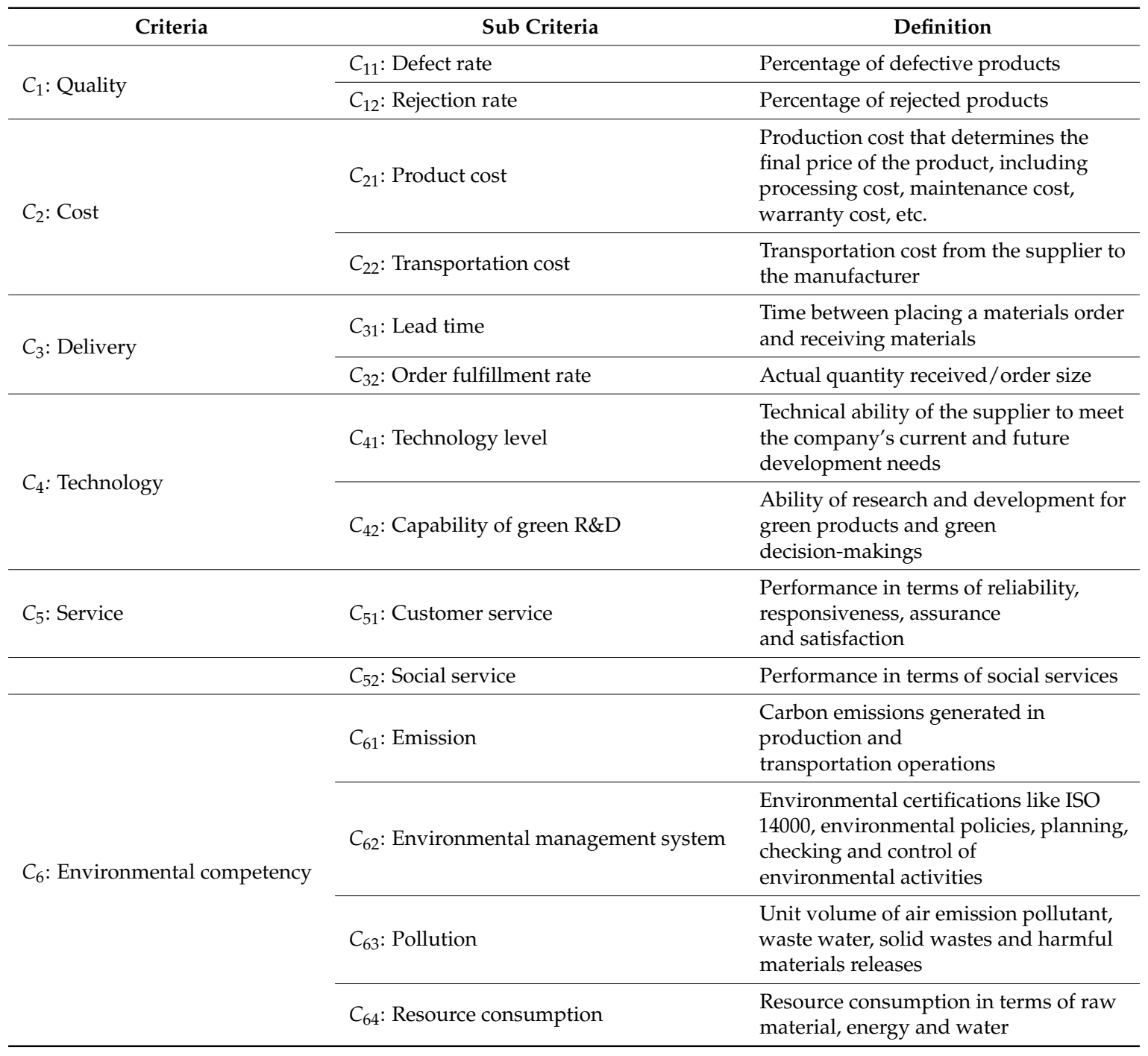




\section{Fuzzy MCDM Model for Green Supplier Selection}

In reality, many indicators cannot be assessed in a quantitative way, which makes decision makers have to face uncertain and fuzzy information. This paper adopts a fuzzy multi-criteria decision-making (MCDM) model based on fuzzy axiomatic design (AD) technique $[65,66]$ to evaluate the performance of alternative suppliers and select the best green supplier for apparel manufacturing. The fuzzy MCDM model is described briefly as follows.

The first step is to transform experts' opinion into triangular fuzzy numbers (TFNs). As shown in Table 1, the green evaluation criteria include tangible and intangible criteria. Tangible criteria include Quality $\left(C_{1}\right)$, Product cost $\left(C_{21}\right)$, Transportation cost $\left(C_{22}\right)$, Emission $\left(C_{23}\right)$, Lead time $\left(C_{31}\right)$, Order fulfillment rate $\left(C_{32}\right)$, Pollution $\left(C_{62}\right)$ and Resource consumption $\left(C_{63}\right)$. Intangible criteria include Technology level $\left(C_{41}\right)$, Capability of green $R \& D\left(C_{42}\right)$ and Environmental management system $\left(C_{61}\right)$. Experts were required to provide their grades for each criterion as a precise numerical value between 0 and 10 (e.g., 5, 6, etc.), a possible range of numerical value between [0, 10] (e.g., 5-6, 7-9), or a linguistic term (e.g., very low, medium, very good, etc.). The individual TFNs are then aggregated into group TFNs according to Equation (1):

$$
\widetilde{W}_{i j}=\frac{1}{N}\left(\widetilde{w}_{i j}^{1}+\widetilde{w}_{i j}^{2}+\ldots+\widetilde{w}_{i j}^{t}+\ldots+\widetilde{w}_{i j}^{N}\right), w_{i j}^{1 t}=\left(a_{i j}, b_{i j}, c_{i j}\right)
$$

where $N$ is the number of experts, $\widetilde{W}_{i j}$ is the ratings of alternatives and $i$ and $j$ denote material supplier $i$ and criterion $j$, respectively.

The second step is to determine functional requirements (FRs) which are the minimal sets of independent requirements. The third step is used to calculate information content for each material supplier. The fourth step is to select the best alternative material supplier which has the minimal total information content value $(I)$. The smaller values of information contents show that the supplier has the better performance with respect to the criterion.

\section{Case Study}

In this section, we applied the proposed framework to a case company for green supplier selection.

\subsection{Case Company}

An apparel manufacturer headquartered in Hong Kong is chosen as the case company, which produces sportswear for many well-known apparel brands all around the world. This company has many plants located in Mainland China and Southeast Asia and purchases raw material worldwide. The case company has a strong incentive to reduce carbon emissions and pollution, which is working on a new project to develop new green products. There are four alternative suppliers located globally. An expert group consisting of three people from the case company is responsible for the green supplier evaluation and selection.

\subsection{Application of Fuzzy MCDM Model}

The evaluation process of the green supplier selection employing the fuzzy MCDM model described in Section 4 was presented as follows.

Step 1. Experts give evaluations for each supplier respect to each criteria by using the linguistic term. Table 2 shows the linguistic assessment of the criteria.

Step 2. After obtaining the linguistic assessments of criteria for each supplier from the experts, this step is to convert them into triangular fuzzy numbers. The evaluation of cost-based criteria is transformed by inverse scoring, which means that if a cost criterion rates very low (VL), it is scored as if it were very high $(\mathrm{VH})$. In the green evaluation criteria proposed. Cost-based criteria include Product cost $\left(C_{21}\right)$, Transportation costs $\left(C_{22}\right)$, Emission $\left(C_{23}\right)$, Lead time $\left(C_{31}\right)$, Pollution production $\left(C_{62}\right)$ and Resource consumption $\left(C_{63}\right)$. 
Table 2. Experts' assessments for the criteria of the alternatives.

\begin{tabular}{|c|c|c|c|c|c|c|c|c|c|c|}
\hline & & \multicolumn{3}{|c|}{ Supplier 1} & \multicolumn{3}{|c|}{ Supplier 2} & \multicolumn{3}{|c|}{ Supplier 3} \\
\hline & & E1 & E2 & E3 & E1 & E2 & E3 & E1 & E2 & E3 \\
\hline \multirow[t]{2}{*}{$C_{1}$} & & 8 & $7-8$ & 7 & 8 & $7-8$ & $\mathrm{~A} 8$ & A8 & 9 & A8 \\
\hline & $C_{21}$ & $\mathrm{~F}$ & $6-7$ & VL & $\mathrm{L}$ & A9 & $\mathrm{M}$ & $\mathrm{H}$ & A6 & $\mathrm{L}$ \\
\hline \multirow[t]{2}{*}{$C_{2}$} & $C_{22}$ & $\mathrm{M}$ & $\mathrm{H}$ & $\mathrm{L}$ & $\mathrm{L}$ & $\mathrm{L}$ & VL & $\mathrm{M}$ & $\mathrm{M}$ & $\mathrm{M}$ \\
\hline & $C_{23}$ & $\mathrm{M}$ & $\mathrm{L}$ & $\mathrm{L}$ & $\mathrm{L}$ & $\mathrm{L}$ & $\mathrm{L}$ & $\mathrm{M}$ & $\mathrm{L}$ & VL \\
\hline \multirow{2}{*}{$C_{3}$} & $C_{31}$ & $7-8$ & A8 & 9 & A8 & 8 & 8 & 7 & $7-8$ & A6 \\
\hline & $C_{32}$ & $\mathrm{H}$ & $8-9$ & $\mathrm{H}$ & 9 & $8-9$ & A9 & A8 & 7 & $\mathrm{H}$ \\
\hline \multirow[b]{2}{*}{$C_{4}$} & $C_{41}$ & $\mathrm{H}$ & $\mathrm{M}$ & A8 & $\mathrm{H}$ & $\mathrm{H}$ & 8 & $\mathrm{VH}$ & $\mathrm{H}$ & $7-8$ \\
\hline & $C_{42}$ & $\mathrm{M}$ & $6-7$ & $\mathrm{M}$ & G & $7-8$ & $\mathrm{~A} 8$ & $\mathrm{G}$ & 8 & G \\
\hline \multirow[t]{2}{*}{$C_{5}$} & & G & VG & 9 & A6 & $\mathrm{G}$ & 6 & $\mathrm{P}$ & F & A4 \\
\hline & $C_{61}$ & $\mathrm{~F}$ & $5-7$ & $\mathrm{~F}$ & $8-9$ & $\mathrm{G}$ & A8 & $6-7$ & A8 & $\mathrm{F}$ \\
\hline \multirow[t]{2}{*}{$C_{6}$} & $C_{62}$ & $\mathrm{M}$ & $\mathrm{M}$ & A5 & $\mathrm{L}$ & $\mathrm{M}$ & $7-8$ & $\mathrm{~L}$ & $7-8$ & A8 \\
\hline & $C_{63}$ & $\mathrm{VH}$ & $\mathrm{H}$ & $\mathrm{H}$ & $\mathrm{L}$ & VL & $\mathrm{M}$ & $\mathrm{M}$ & 7 & 7 \\
\hline
\end{tabular}

Step 3. Calculating the aggregations of the obtained scores according to Equation (1), the aggregation of experts' assessments for supplier 1 was shown in Table 3. For example, the aggregation of "Emission $\left(C_{23}\right)$ " under "Cost $\left(C_{2}\right)$ " for supplier 1 is calculated as follows:

$$
\widetilde{w}_{1 C_{23}}=(4.33,6.67,9)
$$

Table 3. Triangular fuzzy number and converted TFN for supplier 1.

\begin{tabular}{|c|c|c|c|c|c|c|c|c|c|c|c|c|c|c|c|c|}
\hline & & \multicolumn{4}{|c|}{ Supplier 1} & \multicolumn{4}{|c|}{ Supplier 2} & \multicolumn{4}{|c|}{ Supplier 3} & \multirow{2}{*}{\multicolumn{3}{|c|}{$\begin{array}{l}\text { ATNF(System } \\
\text { Range) }\end{array}$}} \\
\hline & & Score & & TNF & & Score & & TNF & & Score & & TNF & & & & \\
\hline \multirow[t]{2}{*}{$C_{1}$} & & 8 & 8 & 8 & 8 & $7-8$ & 7 & 7.5 & 8 & 7 & 7 & 7 & 7 & 7.33 & 7.50 & 7.67 \\
\hline & $C_{21}$ & $\mathrm{~F}$ & 3 & 5 & 7 & $6-7$ & 6 & 6.5 & 7 & VL & 7.5 & 10 & 10 & 5.50 & 7.17 & 8.00 \\
\hline \multirow[t]{2}{*}{$C_{2}$} & $C_{22}$ & M & 3 & 5 & 7 & $\mathrm{H}$ & 0 & 2.5 & 5 & $\mathrm{~L}$ & 5 & 7.5 & 10 & 2.67 & 5.00 & 7.33 \\
\hline & $C_{23}$ & M & 3 & 5 & 7 & $\mathrm{~L}$ & 5 & 7.5 & 10 & L & 0 & 7.5 & 10 & 4.33 & 6.67 & 9.00 \\
\hline \multirow{2}{*}{$C_{3}$} & $C_{31}$ & $7-8$ & 7 & 7.5 & 8 & A8 & 7 & 8 & 9 & 9 & 9 & 9 & 9 & 7.67 & 8.17 & 8.67 \\
\hline & $C_{32}$ & $\mathrm{H}$ & 5 & 7.5 & 10 & $8-9$ & 8 & 8.5 & 9 & $\mathrm{H}$ & 5 & 7.5 & 10 & 6.00 & 7.83 & 9.67 \\
\hline \multirow{2}{*}{$C_{4}$} & $C_{41}$ & $\mathrm{H}$ & 5 & 7.5 & 10 & $\mathrm{M}$ & 3 & 5 & 7 & A8 & 7 & 8 & 9 & 5.00 & 6.83 & 8.67 \\
\hline & $C_{42}$ & $\mathrm{M}$ & 3 & 5 & 7 & $6-7$ & 6 & 6.5 & 7 & $\mathrm{M}$ & 3 & 5 & 7 & 4.00 & 5.50 & 7.00 \\
\hline \multirow[t]{2}{*}{$C_{5}$} & & G & 5 & 7.5 & 10 & VG & 7.5 & 10 & 10 & 9 & 9 & 9 & 9 & 7.17 & 8.83 & 9.67 \\
\hline & $C_{61}$ & $\mathrm{~F}$ & 3 & 5 & 7 & $5-7$ & 5 & 6 & 7 & $\mathrm{~F}$ & 3 & 5 & 7 & 3.67 & 5.33 & 7.00 \\
\hline \multirow[t]{2}{*}{$C_{6}$} & $C_{62}$ & $\mathrm{M}$ & 3 & 5 & 7 & $\mathrm{M}$ & 3 & 5 & 7 & A5 & 4 & 5 & 6 & 3.33 & 5.00 & 6.67 \\
\hline & $C_{63}$ & $\mathrm{VH}$ & 0 & 0 & 2.5 & $\mathrm{H}$ & 0 & 2.5 & 5 & $\mathrm{H}$ & 0 & 2.5 & 5 & 0.00 & 1.67 & 4.17 \\
\hline
\end{tabular}

Step 4. This paper give the definition of functional requirements for each criterion in Figure 2, by combined with the views of the company experts who contribute to the green supplier selection based on the literature. The alternatives must be at least very good (AVG) with respect to the criteria Quality $\left(C_{1}\right)$, Product cost $\left(C_{21}\right)$, Transportation costs $\left(C_{22}\right)$ and Emission $\left(C_{23}\right)$. Moreover, they must satisfy Lead time $\left(C_{31}\right)$, Order fulfillment rate $\left(C_{32}\right)$, Environmental management system $\left(C_{61}\right)$, Pollution production $\left(C_{62}\right)$ and Resource consumption $\left(C_{63}\right)$ at level of at least 7 and the rest criterion must at level of at least good. 


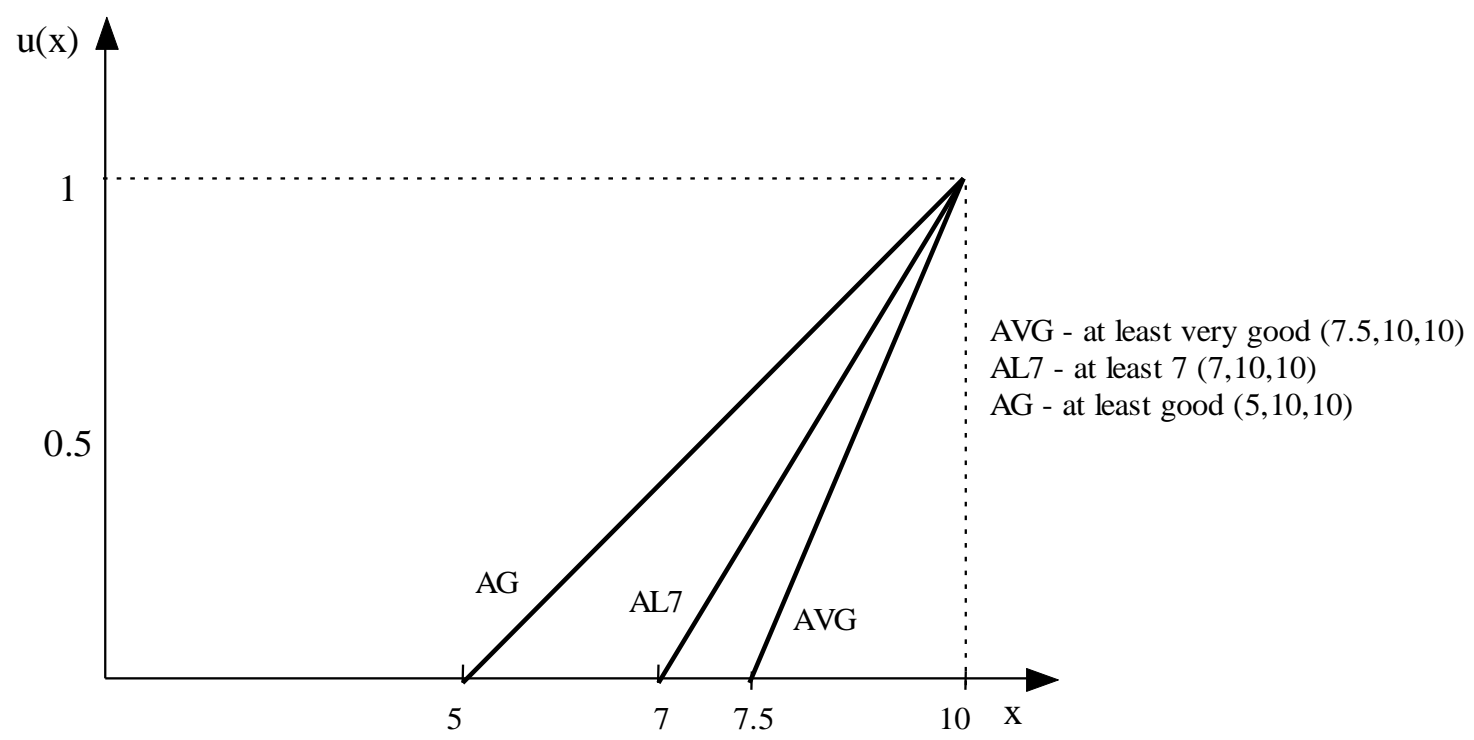

Figure 2. Functional Requirements for defined criteria.

Step 5. As mentioned above, the information content values are computed based on decision-making algorithm with fuzzy information axioms. To illustrate this algorithm, a sample calculation is provided for supplier 1 with respect to the Emission $\left(C_{23}\right)$ criterion was shown in Figure 3.

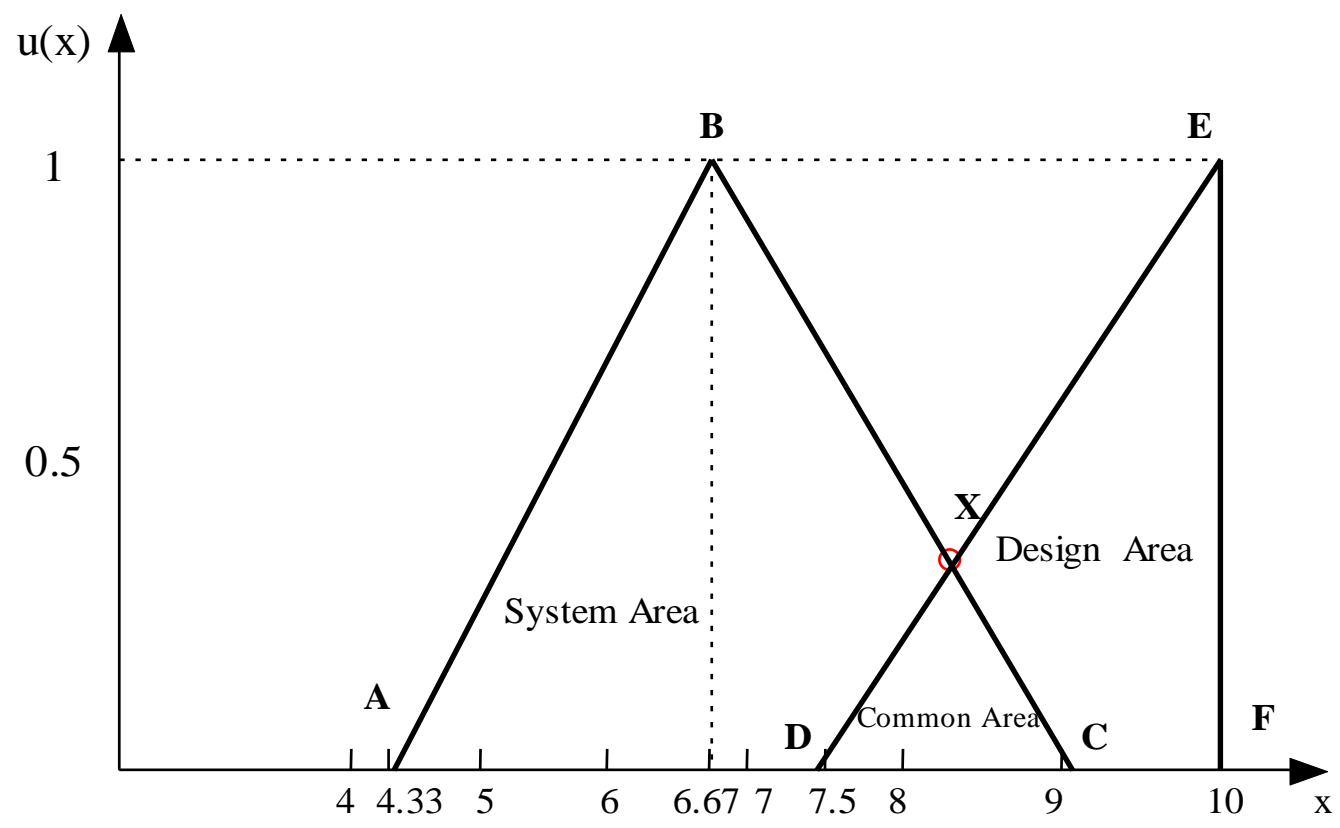

Figure 3. Assessment of "Emission" criterion for the supplier 1.

Table 4 gives the intersecting points of system range and functional requirement. The common area and system area are calculated from the graph by the area calculation method. 
Table 4. Intersecting point from graph plot.

\begin{tabular}{cccccccc}
\hline & \multicolumn{3}{c}{ System Range } & \multicolumn{2}{c}{$\begin{array}{c}\text { Functional Requirement } \\
\text { (Design Range) }\end{array}$} & Intersecting Point \\
\hline & $\mathrm{A}$ & $\mathrm{B}$ & $\mathrm{C}$ & $\mathrm{D}$ & $\mathrm{E}$ & $\mathrm{F}$ & $\mathrm{X}$ \\
\hline$x$ & 4.33 & 6.67 & 9 & 7.5 & 10 & 10 & 8.28 \\
$y$ & 0 & 1 & 0 & 0 & 0 & 1 & 0.31 \\
\hline
\end{tabular}

System Area = 2.3333

Common Area $=0.2325$

So the information content for supplier 1 with respect to the Emission criterion is

$$
I_{1 C_{23}}=\log _{2}\left(\frac{\text { System Area }}{\text { Common Area }}\right)=\log _{2}\left(\frac{2.33}{0.2325}\right)=3.327
$$

\subsection{Results}

The total information content values for each green supplier alternative with respect to the assessments of experts are shown in Table 5. Rows 3-14 show the information content values respects to each criterion, the last row show the total information content values of each supplier. The 3th column presents the FR respects to each criterion, which represents the requirements of decision makers. According to the findings, supplier 2 is selected as the most appropriate green supplier for the case company with respect to the predetermined FRs. Supplier 1 and supplier 3 are eliminated since they don't satisfy all criteria. Supplier 1 is eliminated with respect to the criteria Transportation costs $\left(C_{22}\right)$, Environmental management system $\left(C_{61}\right)$, Pollution production $\left(C_{62}\right)$ and Resource consumption $\left(C_{63}\right)$. Supplier 3 is eliminated with respect to the criteria Product cost $\left(C_{21}\right)$, Transportation costs $\left(C_{22}\right)$, Service $\left(C_{5}\right)$ and Resource consumption $\left(C_{63}\right)$. Supplier 4 satisfies all the criteria but the information content value is higher than that provided by supplier 2 . Therefore, supplier 2 is selected.

Table 5. Information content of each supplier.

\begin{tabular}{|c|c|c|c|c|c|c|}
\hline & & \multirow{2}{*}{ FR } & Supplier 1 & Supplier 2 & Supplier 3 & Supplier 4 \\
\hline & & & $I_{1}^{t}$ & $I_{2}^{t}$ & $I_{3}^{t}$ & $I_{4}^{t}$ \\
\hline \multirow[t]{2}{*}{$C_{1}$} & & $(7.5,10,10)$ & 5.03 & 2.11 & 0.96 & 0.87 \\
\hline & $C_{21}$ & $(7.5,10,10)$ & 5.06 & 2.80 & $\infty$ & 3.14 \\
\hline \multirow[t]{2}{*}{$C_{2}$} & $C_{22}$ & $(7.5,10,10)$ & $\infty$ & 1.47 & $\infty$ & 2.00 \\
\hline & $C_{23}$ & $(7.5,10,10)$ & 3.33 & 2.00 & 2.75 & 5.75 \\
\hline \multirow{2}{*}{$C_{3}$} & $C_{31}$ & $(7,10,10)$ & 0.68 & 0.87 & 5.07 & 3.34 \\
\hline & $C_{32}$ & $(7,10,10)$ & 1.32 & 0.24 & 1.80 & 1.52 \\
\hline \multirow{2}{*}{$C_{4}$} & $C_{41}$ & $(5,10,10)$ & 0.89 & 0.41 & 0.24 & 0.85 \\
\hline & $C_{42}$ & $(5,10,10)$ & 2.27 & 0.39 & 0.41 & 1.19 \\
\hline \multirow[t]{2}{*}{$C_{5}$} & & $(5,10,10)$ & 0.10 & 2.08 & $\infty$ & 0.43 \\
\hline & $C_{61}$ & $(7,10,10)$ & $\infty$ & 1.08 & 4.44 & 0.84 \\
\hline \multirow[t]{3}{*}{$C_{6}$} & $C_{62}$ & $(7,10,10)$ & $\infty$ & 3.11 & 1.54 & 4.13 \\
\hline & $C_{63}$ & $(7,10,10)$ & $\infty$ & 2.12 & $\infty$ & 1.15 \\
\hline & \multicolumn{2}{|c|}{$I^{*}$} & $\infty$ & 18.70 & $\infty$ & 25.22 \\
\hline
\end{tabular}

The proposed framework can not only select the best green supplier, but also help to analyze the suppliers who do not satisfy the case company's requirements. For instance, whereas suppliers 1, 3 and 4 failed to be selected, they were best in some criteria. Supplier 1 is best in criteria Lead time $\left(C_{31}\right)$ and Service $\left(C_{5}\right)$; Supplier 3 is best in Technology level $\left(C_{41}\right)$ and Pollution production $\left(C_{62}\right)$; Supplier 4 did best in Quality $\left(C_{1}\right)$, Environmental management system $\left(C_{61}\right)$ and Resource consumption $\left(C_{63}\right)$, but did worst in 
Emission $\left(C_{23}\right)$. On the basis of the results described above, the decision maker can give suggestions to the suppliers who do not satisfy the required criteria on how to improve their performances.

\subsection{Sensitivity Analysis of FRs Range}

As mentioned above, the design range was obtained based on the knowledge and experience of researchers and practitioners. It is unclear how sensitive the overall decision is to small changes in the design range. Hence, this paper conducts the sensitivity analysis to see the importance of design range (FRs range) in evaluating the performance of suppliers. The FRs ranges for benefit criteria and cost criteria are set to 3 levels respectively, and 9 experiments are conducted based on the combinations of 3 benefit criteria and 3 cost criteria. Table 6 presents the experimental results for sensitivity analysis under the 9 different combinations, in which benefit criteria include $C_{1}, C_{32}, C_{41}, C_{42}, C_{5}, C_{61}$, and cost criteria include $C_{21}, C_{22}, C_{23}, C_{31}, C_{62}$, and $C_{63}$.

In the sensitivity analysis experiments, the FRs range for benefit criteria and cost criteria are set to $(7.5,10,10),(5,10,10),(3,10,10)$, respectively. When the benefit criteria are set in the range $(5,10,10)$ and the cost criteria are taken for all the sets mentioned above, supplier 2 is the best alternative in the cost criteria range of $(5,10,10)$ and $(3,10,10)$. When the benefit criteria are set in the range $(4,10,10)$ against the cost criteria for all 4 ranges, again supplier 2 has the minimum information content value. From the result of sensitivity analysis, it can be seen from Table 6 that by changing the design range, even though the information content is changed, supplier 2 is the best alternative. Out of 9 experiments, supplier 2 has the lowest information content in five experiments, and it shows the decision making process is unaffected by the criteria weights of FRs (design range). The fuzzy MCDM method presented is robust and effective for supplier selection.

Table 6. Experiments for Sensitivity Analysis.

\begin{tabular}{cccccccc}
\hline & \multicolumn{5}{c}{ FR } & \multicolumn{5}{c}{ Information content $\mathbf{c}$} & \multirow{2}{*}{ Rank } \\
\cline { 2 - 6 } & Benefit criteria & Cost criteria & Supplier 1 & Supplier 2 & Supplier 3 & Supplier 4 & \\
\hline 1 & $(7.5,10,10)$ & $(7.5,10,10)$ & $\infty$ & $\infty$ & $\infty$ & $\infty$ & - \\
2 & $(7.5,10,10)$ & $(5,10,10)$ & $\infty$ & $\infty$ & $\infty$ & $\infty$ & - \\
3 & $(7.5,10,10)$ & $(3,10,10)$ & $\infty$ & $\infty$ & $\infty$ & $\infty$ & - \\
4 & $(5,10,10)$ & $(7.5,10,10)$ & $\infty$ & $\infty$ & $\infty$ & $\infty$ & Supplier4 $>$ Supplier2 \\
5 & $(5,10,10)$ & $(5,10,10)$ & $\infty$ & 22.65 & $\infty$ & 30.81 & Supplier4 $>$ Supplier2 \\
6 & $(5,10,10)$ & $(3,10,10)$ & $\infty$ & 13.29 & $\infty$ & 19.54 & Supplier2 \\
7 & $(3,10,10)$ & $(7.5,10,10)$ & $\infty$ & 19.32 & $\infty$ & $\infty$ & Supplier4 $>$ Supplier2 \\
8 & $(3,10,10)$ & $(5,10,10)$ & $\infty$ & 11.76 & $\infty$ & 15.47 & Supplier4 $>$ Supplier2 \\
9 & $(3,10,10)$ & $(3,10,10)$ & $\infty$ & 9.83 & $\infty$ & 12.64 & Sup \\
\hline
\end{tabular}

\section{Conclusions}

This paper presented a systematic hierarchy of green supplier evaluation criteria for apparel manufacturing based on the TBL principle. The definitions of these criteria have been given on the basis of expert interview, investigation and comprehensive literature review. A methodological framework for green supplier evaluation and selection is proposed based on the hierarchy to evaluate the performance of suppliers. And this framework is applied to the supplier selection of a Hong Kong-based apparel manufacturer to validate its effectiveness. The proposed framework was successful in selecting the most suitable green supplier and helping decision makers to analyze the suppliers who did not satisfy the case company's requirements. A sensitivity analysis of FRs range was conducted to verify the framework effectiveness. The framework is easy to use despite the vagueness of experts' opinions in the evaluation process. Future research could compare the performances of the proposed framework with other MCDM methods.

Acknowledgments: The authors would like to thank the financial supports from the Sichuan Science and Technology Project (Grant No. 2017GZ0357), the Sichuan Key Research Bases in Social Sciences (Grant No. Xq16B08) and Sichuan University (Grant No. skqx201725). 
Author Contributions: Zhaoxia Guo conceived and designed the research and wrote the introduction and the methodological framework for green supplier evaluation and selection. Haitao Liu studied and wrote the green supplier evaluation criteria in apparel manufacturing based on the TBL principle. Dongqing Zhang studied and completed the fuzzy MCDM model for green supplier selection. Jing Yang performed the case study and analyzed the data. All authors read and approved the final manuscript.

Conflicts of Interest: The authors declare no conflict of interest.

\section{References}

1. Sen, A. The U.S. fashion industry: A supply chain review. Int. J. Prod. Econ. 2007, 114, 571-593. [CrossRef]

2. Govindan, K.; Khodaverdi, R.; Jafarian, A. A fuzzy multi criteria approach for measuring sustainability performance of a supplier based on triple bottom line approach. J. Clean. Prod. 2013, 47, 345-354. [CrossRef]

3. Lee, H.; Wellan, D.M. Vendor survey plan: A selection strategy for JIT/TQMsuppliers. Ind. Manag. Data Syst. 1993, 93, 8-13. [CrossRef]

4. Shen, B.; Zheng, J.-H.; Chow, P.-S.; Chow, K.-Y. Perception of fashion sustainability in online community. J. Text. Inst. 2014, 105, 971-979. [CrossRef]

5. Guo, S.; Shen, B.; Choi, T.-M.; Jung, S. A review on supply chain contracts in reverse logistics: Supply chain structures and channel leaderships. J. Clean. Prod. 2017, 144, 387-402. [CrossRef]

6. Humphreys, P.; McIvor, R.; Chan, F. Using case-based reasoning to evaluate supplier environmental management performance. Expert Syst. Appl. 2003, 25, 141-153. [CrossRef]

7. Chai, J.; Liu, J.N.; Ngai, E.W. Application of decision-making techniques in supplier selection: A systematic review of literature. Expert Syst. Appl. 2013, 40, 3872-3885. [CrossRef]

8. Igarashi, M.; de Boer, L.; Magerholm Fet, A. What is required for greener supplier selection? A literature review and conceptual model development. J. Purch. Supply Manag. 2013, 19, 247-263. [CrossRef]

9. Lin, R.H. An integrated FANP-MOLP for supplier evaluation and order allocation. Appl. Math. Model. 2009, 33, 2730-2736. [CrossRef]

10. Shen, L.; Olfat, L.; Govindan, K.; Khodaverdi, R.; Diabat, A. A fuzzy multi criteria approach for evaluating green supplier's performance in green supply chain with linguistic preferences. Resour. Conserv. Recycl. 2013, 74, 170-179. [CrossRef]

11. Kulak, O.; Kahraman, C. Multi-attribute comparison of advanced manufacturing systems using fuzzy vs. crisp axiomatic design approach. Int. J. Prod. Econ. 2005, 95, 415-424. [CrossRef]

12. Dickson, G.W. An analysis of vendor selection systems and decisions. J. Purch. 1996, 2, 5-17.

13. Weber, C.A.; Current, J.R.; Benton, W.C. Vendor selection criteria and methods. Eur. J. Oper. Res. 1991, 50, 2-18. [CrossRef]

14. Noci, G. Designing "green" vendor rating systems for the assessment of a suppliers environmental performance. Eur. J. Purch. Supply Manag. 1997, 3, 103-114. [CrossRef]

15. Lu, L.Y.Y.; Wu, C.H.; Kuo, T.C. Environmental principles applicable to green supplier evaluation by using multi-objective decision analysis. Int. J. Prod. Res. 2007, 45, 4317-4331. [CrossRef]

16. Lee, A.H.I.; Kang, H.Y.; Hsu, C.F.; Hung, H.C. A green supplier selection model for high-tech industry. Expert Syst. Appl. 2009, 36, 7917-7927. [CrossRef]

17. Grisi, R.M.; Guerra, L.; Naviglio, G. Supplier performance evaluation for green supply chain management. Bus. Perform. Meas. Manag. 2010, 4, 149-163.

18. Chen, C.C.; Tseng, M.L.; Lin, Y.H.; Lin, Z.S. Implementation of green supply chain management in uncertainty. In Proceedings of the 2010 IEEE International Conference on Industrial Engineering and Engineering Management (IEEM), Macao, China, 7-10 December 2010; pp. 260-264.

19. Kuo, R.J.; Lin, Y.J. Supplier selection using analytic network process and data envelopment analysis. Int. J. Prod. Res. 2012, 50, 2852-2863. [CrossRef]

20. Kannan, D.; Govindan, K.; Rajendran, S. Fuzzy Axiomatic Design approach based green supplier selection: A case study from Singapore. J. Clean. Prod. 2015, 96, 194-208. [CrossRef]

21. Genovese, A.; Koh, S.C.L.; Bruno, G.; Esposito, E. Greener supplier selection: State of the art and some empirical evidence. Int. J. Prod. Res. 2013, 51, 2868-2886. [CrossRef]

22. Elkington, J. Partnerships from cannibals with forks: The triple bottom line of 21st-century business. Environ. Qual. Manag. 1998, 8, 37-51. [CrossRef] 
23. Hubbard, G. Measuring organizational performance: Beyond the triple bottom line. Bus. Strategy Environ. 2009, 18, 177-191. [CrossRef]

24. Li, Q.; Shen, B. Sustainable Design Operations in the Supply Chain: Non-Profit Manufacturer vs. For-Profit Manufacturer. Sustainability 2016, 8, 639. [CrossRef]

25. Hall, T.J. The triple bottom line: What is it and how does it work? Indiana Bus. Rev. 2011, 86, 4.

26. Pope, J.; Annandale, D.; Morrison-Saunders, A. Conceptualising sustainability assessment. Environ. Impact Assess. Rev. 2004, 24, 595-616. [CrossRef]

27. Rogers, M.; Ryan, R. The triple bottom line for sustainable community development. Local Environ. 2001, 6, 279-289. [CrossRef]

28. Dong, C.; Shen, B.; Chow, P.-S.; Yang, L.; Ng, C.T. Sustainability investment under cap-and-trade regulation. Ann. Oper. Res. 2016, 240, 509-531. [CrossRef]

29. Chan, H.-L.; Shen, B.; Cai, Y. Quick response strategy with cleaner technology in a supply chain: Coordination and win-win situation analysis. Int. J. Prod. Res. 2017, 1-12. [CrossRef]

30. Nikolaou, I.E.; Evangelinos, K.I.; Allan, S. A reverse logistics social responsibility evaluation framework based on the triple bottom line approach. J. Clean. Prod. 2013, 56, 173-184. [CrossRef]

31. Sarkis, J.; Dhavale, D.G. Supplier selection for sustainable operations: A triple-bottom-line approach using a Bayesian framework. Int. J. Prod. Econ. 2015, 166, 177-191. [CrossRef]

32. Shen, B.; Choi, T.-M.; Wang, Y.; Lo, C.K. The coordination of fashion supply chains with a risk-averse supplier under the markdown money policy. IEEE Trans. Syst. Man Cybern. Syst. 2013, 43, 266-276. [CrossRef]

33. Shen, B. Sustainable fashion supply chain: Lessons from H\&M. Sustainability 2014, 6, 6236-6249.

34. Shen, B.; Li, Q. Impacts of returning unsold products in retail outsourcing fashion supply chain: A sustainability analysis. Sustainability 2015, 7, 1172-1185. [CrossRef]

35. Tseng, M.; Chiang, J.H.; Lan, L.W. Selection of optimal supplier in supply chain management strategy with analytic network process and choquet integral. Comput. Ind. Eng. 2009, 57, 330-340. [CrossRef]

36. Vinodh, S.; AneshRamiya, R.; Gautham, S.G. Application of fuzzy analytic network process for supplier selection in a manufacturing organisation. Expert Syst. Appl. 2011, 38, 272-280. [CrossRef]

37. $\mathrm{Ng}, \mathrm{W} . \mathrm{L}$. An efficient and simple model for multiple criteria supplier selection problem. Eur. J. Oper. Res. 2008, 186, 1059-1067. [CrossRef]

38. Singh, R.K.; Kumar, P.; Gupta, V. Fuzzy statistical approach forvendorselection in supply chain. Int. J. Logist. Syst. Manag. 2010, 7, 286-301. [CrossRef]

39. Wu, T.; Blackhurst, J. Supplier evaluation and selection: An augmented DEA approach. Int. J. Prod. Res. 2009, 47, 4593-4608. [CrossRef]

40. Falagario, M.; Sciancalepore, F.; Costantino, N.; Pietroforte, R. Using a DEA-crossefficiency approach in public procurement tenders. Eur. J. Oper. Res. 2012, 218, 523-529. [CrossRef]

41. Vahdani, B.; Jabbari, A.H.K.; Roshanaei, V.; Zandieh, M. Extension of the ELECTRE method for decision-making problems with interval weights and data. Int. J. Adv. Manuf. Technol. 2010, 50, 793-800. [CrossRef]

42. Liu, P.; Zhang, X. Research on the supplier selection of a supply chain based on entropy weight and improved ELECTRE-III method. Int. J. Prod. Res. 2011, 49, 637-646. [CrossRef]

43. Crispim, J.A.; de Sousa, J.P. Partner selection in virtual enterprises. Int. J. Prod. Res. 2010, 48, 683-707. [CrossRef]

44. Deng, Y.; Chan, F.T.S. A new fuzzy dempster MCDM method and its application in supplier selection. Expert Syst. Appl. 2011, 38, 9854-9861. [CrossRef]

45. Sarkar, A.; Mohapatra, P.K.J. Evaluation of supplier capability and performance: A method for supply base reduction. J. Purch. Supply Manag. 2006, 12, 148-163. [CrossRef]

46. Ferreira, L.; Borenstein, D. A fuzzy-bayesian model for supplier selection. Expert Syst. Appl. 2012, 39, 7834-7844. [CrossRef]

47. Handfield, R.; Walton, S.V.; Sroufe, R.; Melnyk, S.A. Applying environmental criteria to supplier assessment: A study in the application of the analytical hierarchy process. Eur. J. Oper. Res. 2002, 141, 70-87. [CrossRef]

48. Levary, R.R. Using the analytic hierarchy process to rank foreign suppliers based on supply risks. Comput. Ind. Eng. 2008, 55, 535-542. [CrossRef]

49. Amid, A.; Ghodsypour, S.H.; O'Brien, C. A weighted max-min model for fuzzy multi-objective supplier selection in a supply chain. Int. J. Prod. Econ. 2011, 131, 139-145. [CrossRef] 
50. Hsu, C.W.; Hu, A.H. Application of analytic network process on supplier selection to hazardous substance management in green supply chain management. In Proceedings of the International Conference on Industrial Engineering and Engineering Management (IEEM), Singapore, 2-4 December 2007; pp. 1362-1368.

51. Hsu, C.W.; Hu, A.H. Applying hazardous substance management to suppliers election using analytic network process. J. Clean. Prod. 2009, 17, 255-264. [CrossRef]

52. Kumar, A.; Jaina, V.; Kumar, S. A comprehensive environment friendly approach for supplier selection. Omega 2014, 42, 109-123. [CrossRef]

53. Che, Z.H. A genetic algorithm-based model for solving multi-period supplier selection problem with assembly sequence. Int. J. Prod. Res. 2010, 48, 4355-4377. [CrossRef]

54. Chiou, T.Y.; Chan, H.K.; Lettice, F.; Chung, S.H. The influence of greening the suppliers and green innovation on environmental performance and competitive advantage in Taiwan. Transp. Res. 2011, 47, 822-836. [CrossRef]

55. Feyzioglu, O.; Büyüközkan, G. Evaluation of green suppliers considering decision criteria dependencies. In Multiple Criteria Decision Making for Sustainable Energy and Transportation Systems; Springer: Berlin/Heidelberg, Germany, 2010; pp. 145-154.

56. Large, R.O.; Thomsen, C.G. Drivers of green supply management performance: Evidence from Germany. J. Purch. Supply Manag. 2011, 17, 176-184. [CrossRef]

57. Wang, J.; Cheng, C.; Huang, K. Fuzzy hierarchical TOPSIS for supplier selection. Appl. Soft Comput. J. 2009, 9, 377-386. [CrossRef]

58. Yan, G. Research on green suppliers' evaluation based on AHP \& genetic algorithm. In Proceedings of the International Conference on Signal Processing Systems, Singapore, 15-17 May 2009; pp. 615-619.

59. Kannan, D.; Khodaverdi, R.; Olfat, L.; Jafarian, A.; Diabat, A. Integrated fuzzy multi criteria decision making method and multiobjective programming approach for supplier selection and order allocation in a green supply chain. J. Clean. Prod. 2013, 47, 355-367. [CrossRef]

60. Eraslan, E.; Akay, D.; Kurt, M. Usability ranking of intercity bus passenger seats using fuzzy axiomatic design theory. In Proceedings of the International Conference on Cooperative Design, Visualization and Engineering, Mallorca, Spain, 17-20 September 2006; Springer: Berlin, Germany, 2006; pp. 141-148.

61. Gonçalves-Coelho, A.M.; Mourão, A.J.F. Axiomatic design as support for decision-making in a design for manufacturing context: A case study. Int. J. Prod. Econ. 2007, 109, 81-89. [CrossRef]

62. Celik, M.; Kahraman, C.; Cebi, S.; Er, I.D. Fuzzy axiomaticdesign-based performance evaluation model for docking facilities in ship building industry: The case of Turkish shipyards. Expert Syst. Appl. 2009, 36, 599-615. [CrossRef]

63. Buyukozkan, G.; Arsenyan, J.; Ruan, D. Logistics tool selection with two-phase fuzzy multi criteria decision making: A case study for personal digital assistant selection. Expert Syst. Appl. 2012, 39, 142-153. [CrossRef]

64. Ozel, B.; Ozyoruk, B. Supplier selection with fuzzy axiomatic design. J. Fac. Eng. Archit. Gazi Univers. 2007, 22, 415-423.

65. Suh, N.P. Axiomatic design theory for systems. Res. Eng. Des. 1998, 10, 189-209. [CrossRef]

66. Govindan, K.; Rajendran, S.; Sarkis, J.; Murugesan, P. Multi criteria decision making approaches for green supplier evaluation and selection: A literature review. J. Clean. Prod. 2015, 98, 66-83. [CrossRef]

(C) 2017 by the authors. Licensee MDPI, Basel, Switzerland. This article is an open access article distributed under the terms and conditions of the Creative Commons Attribution (CC BY) license (http:/ / creativecommons.org/licenses/by/4.0/). 